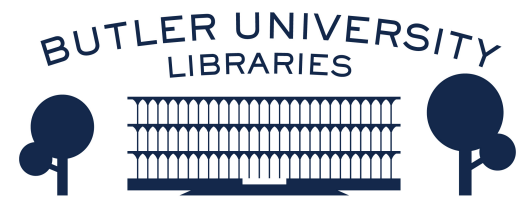

Journal of Hindu-Christian Studies

Volume 32 Discussion of Nathaniel Roberts, To

Be Cared For: The Power of Conversion and

Article 13

Foreignness of Belonging to An Indian Slum.

2019

\title{
Book Review: Imaginations of Death and the Beyond in India and Europe
}

Herman Tull

Lafayette College

Follow this and additional works at: https://digitalcommons.butler.edu/jhcs

\section{Recommended Citation}

Tull, Herman (2019) "Book Review: Imaginations of Death and the Beyond in India and Europe," Journal of Hindu-Christian Studies: Vol. 32, Article 13.

Available at: https://doi.org/10.7825/2164-6279.1739

The Journal of Hindu-Christian Studies is a publication of the Society for Hindu-Christian Studies. The digital version is made available by Digital Commons @ Butler University. For questions about the Journal or the Society, please contact cbauman@butler.edu. For more information about Digital Commons @ Butler University, please contact digitalscholarship@butler.edu. 
multivalence of saintliness-and its moral ambiguity-may have helped inform the various, otherwise excellent, discussions.

That being said, this volume fills a yawning gap in interreligious study, and it is very well executed. The structure is logical, the writing clear, and the subject compelling. I found it academically and spiritually stimulating and commend it to anyone who seeks to learn more about those extraordinarily abundant human beings whom we call saints.

Jon Paul Sydnor

Emmanuel College (Boston)

\section{Imaginations of Death and the Beyond in India and Europe. Edited by Günter Blamberger and Sudhir Kakar. Singapore: Springer Nature, 2018, ix + 202 pages.}

THIS volume brings together twelve essays from a 2014 conference, "Figurations of Afterlife/Afterdeath," held in New Delhi and funded by the German Federal Ministry of Education and Research. As noted in the volume's brief, unattributed introduction, the central concern of the conference was to ask "How can literature and the arts in general help us cope with [the] knowledge of death?" (vii). Underlying this question is the problematic nature of the knowledge of death itself; indeed, as the author of the introduction notes, death, which characteristically is laden with uncertainty, carries us "beyond all rational analysis" (vii).

Yet, whereas an earlier age looked to the world of religion to approach the unknowable, as editor and contributor Günter Blamberger observes, "religion has lost its influence as a common master discourse providing answers to fundamental problems..." (21). Blamberger suggests that in its place, in the modern world, "what really matters is that almost everybody pays attention to the artifacts of literature, of the arts, or of mass media to study their depiction and their reading of traditionally religious questions of disease and death, good and bad, justice and injustice, love and grief, community and solitude" (21). This notion of the arts as a repository of what was once located in traditional religious discourse recurs throughout the volume, as individual essays delve broadly into modern film, literature, and the created worlds of social and political discourse. However, alongside this core, traditional religious notions are cited over and again; in particular, mythologies of the afterlife and deathways are treated in several essays, and are appealed to in others as points of contrast.

The twelve essays are grouped under four headings: Initial Questions (consisting of two essays by the editors Kakar and Blamberger that loosely frame the collection as a whole); Questions of Immortality; Questions of Visuality; and Questions of Transition. Interspersed in each section are essays that discuss European notions of death and the afterlife (the majority of the essays) with others that consider Indic materials. These two nodes (European and Indic) are set off by a brief introductory section that juxtaposes a Grimm story of an encounter with Godfather Death with the famed Kathopanishad (ca. 5th c. BCE) tale of the meeting between the brahmin boy Nachiketas and the God of Death (Yama). 
The individual essays are of high quality. Noteworthy elements include Blamberger's wide-ranging rumination ("Threshold Images Between Life and Death in Western Literature and Film") on the "replacement" of traditional religious notions with images and ideas drawn from literature and mass media, "as if they were myths of evidence" (22). Here, Blamberger moves from Kafka, to the 1990 film Flatliners, to modern German poetry, to Mann's Magic Mountain, skillfully eliciting "traditional" resonances throughout: the Grim Reaper of medieval Christian allegory; death as the punishment for the Fall; the figures of Charon and Jesus. Jonardon Ganeri's remarkable essay ("Illusions of Immortality") sets the notions of death, selfhood, and consciousness put forth by the famed fifth century Buddhist scholiast Buddhaghosa against the perception of the unknowable and hence uncertain nature of death found in the work of the modern Portuguese poet Fernando Pessoa. Ganeri's carefully wrought comparison leads to deep questions of the nature of consciousness and subjectivity, (the "me" and the "not-me"), "...and the combination of absolute familiarity and total alienation is indeed terrifying" (44). Other deeply fascinating studies are Oliver Krüger's essay ("The Quest for Immortality as a Technical Problem: The Idea of Cybergnosis and the Visions of Posthumanism") on the implications of freedom from a mortal body in a posthuman, cyborg existence; that is, effectively a state of immortality, but one in which human concerns (sexual pleasure, materialism in general) would still impinge upon existence, hence raising a number of troubling moral questions.

Among the essays treating Indic materials is Nama Ahuja's "The Dead, Dying, and PostDeath: Visual Exemplars and Iconographic Devices," which presents a detailed conspectus of Indian "monuments for the dead" along with a wide selection of iconographic associations of Indian gods with death. This is an unstudied field, yet with a range of elements that Ahuja shows to have been "in plain sight" in myth, temple art, and literature. Better known in India are the associations of the city of Varanasi (Kashi) with death, India's most prized locale (on the banks of the Ganges) for the performance of funeral rites, the subject of Katherine Kakar's essay ("Afterlife and Fertility in Varanasi"). Here, Kakar looks to the underlying element of fertility, death's “opposite," yet long known in the anthropological literature (188) to be coexistent with it.

A number of the essays move nimbly between India and the West. Editor and contributor Sudhir Kakar ("Moksha: On the Hindu Quest for Immortality") considers both traditional Indian views of death and what lies beyond, while lading his insights with references to Freud and modern Western studies of near-death experiences. Kakar's essay is written in the form of a dialogue between skeptic and believer, suggesting not only his own inner dialogue, but recalls the format of Mohandas Gandhi's famed 1909 manifesto Hind Swaraj or Indian Home Rule. Thomas Macho's “Paths to Nirvana? Hunger as Practice of Suicide," though primarily focused on images of death and the beyond that are drawn from current cinema, deftly locates the modern representation of suicide within the Japanese practice of ritual suicide and selfmummification.

Although less a collection than an eclectic mix, a point accentuated by the lack of an introductory synoptic narrative-something generally seen in volumes of this sort-the individual essays are invariably thoughtprovoking, and in many cases, highly innovative. The work is recommended not 
only for those with an interest in representations of death and what lies beyond, but also for those engaged in studying the intersection of the modern and the traditional. Although the material is not specifically comparative, there is much to be gleaned from the volume's cross-cultural presentation.

Herman Tull

Lafayette College

\section{Keshab: Bengal's Forgotten Prophet. By John A. Stevens. Oxford: Oxford University Press, 2018, 309 pages.}

KESHAB CHANDRA SEN (1838-1884) was the founder of the Brahmo Samaj of India, a splinter group from the original Brahmo Samaj initiated by Rammohan Roy in 1828 . Roy's Samaj began as a reformed version of Hinduism, without image worship and drawing upon the Upanishads. It was later led by Debendranath Tagore. Today, Sen is somewhat of a forgotten figure, but in the 1860s, he was popular among the Western educated of Kolkata as a religious and social reformer. Later, given that some of his positions and actions were inconsistent and controversial, and given that Indian nationalism emerged as the new trend, he was reviled. A century later, in the 1970s, there was much research on Sen and related figures. In 1979, David Kopf published the foundational study, The Brahmo Samaj and the Shaping of the Indian Mind. John Stevens's new book sheds further light on Sen and shows that he continues to be a relevant focus of research.

Sen was raised in a Vaishnava family in Bengal. However, under the influence of a Western education, he dropped his religious background. He spent time with Christian missionaries, but instead of becoming Christian he joined Tagore's Brahmo Samaj. Sen drew many young people into the Samaj. However, tensions grew between the younger and older generations, and Sen thus led a splinter group, the Brahmo Samaj of India. No longer under the tutelage and authority of Tagore, Sen explored a wide variety of interests with his splinter group. These included Vaishnava devotionalism, Advaitic notions of unity, Hindu stories and rituals, Sri Ramakrishna, Jesus Christ, Christian evangelicalism, Thomas Carlyle's philosophy, and English approaches to social reform. Given the many shifts in Sen's thought and actions, he came to be widely criticized and a third group, the Sadharan Brahmo Samaj, splintered from his organization.

How does one make sense of this selfprofessedly eclectic figure? In his 1979 study, Kopf identified him as a "prophet of interreligious harmony." One would like more clarity on this issue: in what way was he a prophet? How, for instance, did his approach differ from the approaches of later figures like Swami Vivekananda and John Hick? Stevens offers a key: Sen's approach was performative. He tried to bridge religions by enacting aspects of them, "embodying them in his own person" in order to effect a unity "that did not exist in reality" (224). His best-known attempts, in that regard, were his theatrical celebrations in 1880 of various saints and wise men from across the world, and his performance, in 1881, of new, hybridized religious rituals.

Stevens's study also sheds light on the relationship between Sen and the newly 